\title{
IMPACT OF WATER MANAGEMENT ON PRODUCTION OF RICE IN BALIPATNA COMMAND AREA OF ORISSA, INDIA
}

\author{
G.P Reddy ${ }^{1}$
}

\begin{abstract}
In order to know the impact of improved water management practices a study was conducted at Balipatna block under canal irrigation command to know the economic feasibility of water management through field channels. Data from 30 farmers practicing irrigation through field channels and 30 farmers who are irrigating fields without field channels were collected with help of specially designed questionnaire. In order to know the impact of field channels, a multiple stepwise regression analysis with dummy variable to catch impact of field channels was done. The results indicated that irrigation through field channels had positive impact on the yield of kharif paddy. The variables like application of fertilizers, irrigation cost, seed and labour cost had significant positive impact on the paddy yields. The marginal productivity of inputs indicated fertilizers and seeds are not efficiently utilized compared other inputs. Hence, extension should be under taken to improve application of fertilizer in a more scientific way and encourage the use of yielding varieties to improve yields of paddy
\end{abstract}

Key words: Water Management, Canal Irrigation, Economic Feasibility, Catch Impact

\section{INTRODUCTION}

Agriculture is of fundamental importance in India's economy. It contributes $28 \%$ of GDP $(1995 / 96)$ and $67 \%$ of employment (1990/91), while investments in agriculture amount to some $11 \%$ of gross domestic investment. It generates some $10 \%$ of total exports, and following the economic liberalization program commenced in the early 1990s; agricultural commodities are among India's fastest growing export sectors. Most crucial of all is agriculture's role as a provider of livelihood for the majority of the population, and food security for the nationals as a whole. Irrigation is everything in India. Water is more valuable than land, because when water is applied to land it increases its productivity at least six fold and renders great extent of land productive in India.
Expansion of Agriculture over last five decades has been made possible mainly through expansion of irrigation Various analysis of the role of irrigation in India's agriculture have shown that irrigated has played a core role in agricultural production and growth. Although gross irrigated area (currently about 90 million ha, includes double cropping) is a minority-about one -third of total cropped area in India- the production from irrigated lands greatly exceeds the productivity of rain fed farming. In a monsoon dependent farming system, with rains unreliable and large areas with rainfall less than $1,000 \mathrm{~mm}$ per annum, irrigation has been a crucial input for agricultural production. Irrigation enables a higher productive potential from the land, and significant production response from associated use of high yielding varieties, fertilizer and other inputs. Both at the

${ }^{1}$ Sr.Scientist (Agril-Economics), National Academy of Agricultural Research Management, Rajendranagar, 
national and regional levels, agricultural growth and rural development have closely followed the growth and regional pattern.

Planned development of irrigation after independence helped in development of agriculture. However, unplanned use of irrigation water led to many water related problems, which made irrigation of fields uneconomical. Hence proper application of water will not only increase the productivity of crops but also increases the area under the irrigation. To know the economic feasibility of irrigation through field channels a study was conducted at Balipatna Block command area of Puri main canal of Orissa.

\section{METHODOLOGY}

\section{Study area}

Hirakud Dam project across the river Mahanadi is main source of mahanadi delta irrigation-II project .The command area of delta stage -II project covers small area of Puri district having a gross command area of 2.55 lakh.hectares and cultivable Command area of 1.36-lakh hectare the first reach of Puri main canal having a total length of $41.85 \mathrm{~km}$ besides the main canal, the distribution network consists of seven branch canals. Nimpara branch canal is one of them under which Balipatna block is irrigated.

\section{Data and Analysis}

The data from about 30 farmers practicing irrigation through field channels and equal number of farmers who are irrigating their fields without field channels are collected with the help of specially designed questionnaire.
The present paper attempts to examine the nature of technological impact on paddy production, through the measurement of productivity difference between beneficiary and non-beneficiary of water management practices and evaluating the constituent sources of such a difference.

\section{Data}

The primary data required for the study were collected through a survey of 30 farmers each from, both from beneficiary and non-beneficiary farmers during the period 2003-2004

\section{Specification of the model}

Two types of algebraic forms viz, Linear as well as Cobb-Douglas forms were tried by least square method in the present study:

Linear: $Y=a+\sum_{i=1}^{4} b_{i} x_{i}$
Cobb Douglas; $Y=a+\prod_{i=1}^{4} X_{i}$

Where $\mathrm{Y}=$ Returns per hectare Rice (RS/ha)

$\mathrm{X}_{1}=$ Area under the crop (ha)

$\mathrm{X}_{2}=$ Expenditure on seeds $(\mathrm{RS} / \mathrm{ha})$

$\mathrm{X}_{3}=$ Expenditure on Fertilizer $(\mathrm{RS} / \mathrm{ha})$

$\mathrm{X}_{4}=$ Expenditure on human labour (RS/ha)

' $a$ ' is the intercept; $b_{i} s$ are regression Coefficient associated with explanatory variables Xi. ${ }^{\text {s }}$ 
The Cobb-Douglas production function was finally selected for the present investigation, because it has given best fit and the expected input-output relationships.

No serious multicollinearity was observed between any pair of explanatory variables under study as per the criteria suggested by Klein.

For any given production function the total charge in output is brought about by the shifts in the parameters and by changes in the volume of input. The impact of watershed programme (neutral and non-neutral) was examined by testing equality of gross income elasticities with respect to various inputs with separate regressions for beneficiary and non-beneficiary groups of the rice growers by allowing the constant terms in the two production functions to differ, i.e. with the help of formulation of hypothesis:

Ln $\mathbf{A}_{1} \neq \mathbf{1 n} \mathbf{A}_{2}$. The Rice production function for non-beneficiary and beneficiary group can be written in $\log$ linear from as:

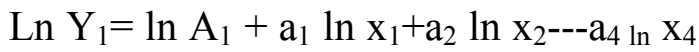
$+\mathrm{u}_{1}$

$\operatorname{Ln} \mathrm{Y}_{2}=\ln \mathrm{A}_{2}+\mathrm{a}^{*}{ }_{1} \ln \mathrm{x}_{1}{ }^{*}+\mathrm{a}_{2}{ }^{*} \operatorname{In} \mathrm{x}_{2}{ }^{*--}$ $\mathrm{a}_{4} * \ln \mathrm{x}_{4} *+\mathrm{u}_{2}$

Where $Y_{1}$ and $Y_{2}$ are the gross income from rice crop for the non-beneficiary and beneficiary farmers, respectively and $\mathrm{x}_{1}$ and $\mathrm{x}_{1} *$ are the connected variables. Taking the difference between the production functions (2) and (1) and adding subtracting the same terms, the modified decomposition model given by Alshi (1981) was employed. The form of the model is
$\left(\mathrm{Y} / \mathrm{Y}_{1}\right)=\left[\sigma \ln \left(\mathrm{A}_{2} / \mathrm{A}_{1}\right)\right]+\left[\sigma\left(\mathrm{a}_{1}{ }^{*} \mathrm{a}_{1}\right) \ln \right.$ $\mathrm{x}_{1}+\sigma\left(\mathrm{a}_{1} *-\mathrm{a}_{2} *\right) \ln \mathrm{x}_{2}+\ldots+\left[\sigma\left(\mathrm{a}_{4} *-\mathrm{a}_{4}\right) \ln \mathrm{x}_{4}\right.$ )$+\left[\sigma \mathrm{a}_{1} * \ln \left(\mathrm{x}_{1} * / \mathrm{x}_{1}+\sigma \mathrm{a}_{2} * \ln \left(\mathrm{x}_{2} * / \mathrm{x}_{2}\right)\right.\right.$ $\left.+\ldots+\sigma \mathrm{a}_{4} * \ln \left(\mathrm{x}_{4} * / \mathrm{x}_{4}\right)\right]$

Where $\sigma=\left(\mathrm{Y} / \mathrm{Y}_{1}\right) / \ln \left(\mathrm{Y}_{2} / \mathrm{Y}_{1}\right)$, and $\mathrm{Y}=\mathrm{Y}_{2}-\mathrm{Y}_{1}$

The income decomposition model (3) decomposes the total differences in gross income from rice crop on the beneficiary and non-beneficiary groups of farmers into the following three forces.

1. Neutral change because of the status of beneficiary and non-beneficiary.

2. Non-neutral change because of the status of beneficiary and nonbeneficiary and

3. Change in the levels of inputs.

The bracketed expression on the left hand side of the decomposition equation (3) is a measure of the percentage change in income because of the status of beneficiary. The first bracketed expression on the right hand side of the above equation is a measure of percentage change in gross income due to technological change because of the status of beneficiary of the watershed project. The second bracketed expression is the sum of the differences in gross income elasticity each weighted by the natural logarithms of the levels of the inputs used. This gives the measure of change in income due to non-neutral technology. The third bracketed expression is the sum of natural logarithms of the ratio of the inputs used on the non-beneficiary and beneficiary rice growers, each weighted by the income elasticity of that input. This expression measures the change in income due to changes in the levels of inputs at the given income elasticity of these inputs on the rice crop by the beneficiary farmers. In the third bracket, 
the middle bracketed expressions capture the effect of difference in the levels of different inputs used by the beneficiary and non-beneficiary groups of farmers.

\section{RESULTS AND DISCUSSIONS}

The results of geometric measures of all the inputs were relatively higher in case of beneficiary respectively (Table 01 ). The results of regression analysis revealed that the percent variation in the gross income from rice productions has been explained by the explanatory variables in case of beneficiary and nonbeneficiary farmers groups respectively (Table 02).

\section{Table 01: Geometric measures of input and output in Rice production (RS/ha)}

\begin{tabular}{|c|c|c|}
\hline \multirow[t]{2}{*}{ Variables } & \multicolumn{2}{|c|}{ Geometric measure } \\
\hline & Beneficiary & Non-beneficiary \\
\hline Human labour & 2269 & 1589 \\
\hline Fertilizer & 1115 & 1084 \\
\hline Seed & 695 & 633 \\
\hline Returns & 7272 & 4137 \\
\hline
\end{tabular}

Table 02: Regression co-efficient of input and output in Rice production.

\begin{tabular}{lcc}
\hline Variable & \multicolumn{2}{c}{ Regression co-efficient } \\
& $0.1470^{*}$ & Beneficiary Human \\
\hline Labour & $0.1477^{* *}$ & $0.3855^{*}$ \\
Fertilizer & $0.0561^{* *}$ & $0.0135^{*}$ \\
Seeds & 0.5 .862 & $-0.0179^{*}$ \\
Constant & & 6.010 \\
\hline
\end{tabular}

* Significant at $1 \%$ level

**significant at 5\% level 
The decomposition equation given in the methodology provides the mechanism for decomposing the total difference in gross income between beneficiary and non-beneficiary groups of rice producers. The results are presented in Table 03. It can be observed from the results that the total change in the gross income between beneficiary and nonbeneficiary rice producers was 56.41 percent.

When both neutral and non-neutral components are added, an approximate measure of the contribution of water management practices to the gross income difference between beneficiary and non-beneficiary rice produces is obtained. Both these variables together contribute positively to the total gain. The positive contribution of the both components together indicates that the value of rice yields per hectare would be more in respect of beneficiaries, even if they use the same levels of inputs as compared to the non-beneficiaries. This implies that implementation of water management practices brought about an immediate upward shift in the threshold level of gross income from rice production because of optimal use of water and availability of same during critical growth of rice crop results in higher yields and thereby income. This is in agreement with the results obtained by Kumar et al (1989) and Vekariya and Shiyani (1999).

Third component (input use) contributed 43.09 percent. The contribution of each input indicated that some inputs contributed positively. The positive contribution implied that the beneficiary group of farmers is better allocators of inputs. While in usage of manure however non-beneficiaries have an advantage over the beneficiary in the rice production.

\section{CONCLUSIONS}

The major findings that emerged from the study show that the values of geometric means of all the inputs were relatively higher incase of beneficiary farmers. Thus, the beneficiary enjoyed a higher gain in the gross income as compared to the gain realized by the non-beneficiaries. The results of decomposition analysis revealed that the income from water management practices in respect of beneficiaries would be more, even if they use same levels of inputs when compared to nonbeneficiaries indicating that the water

Table 03: Decomposition of Total difference in gross income between beneficiary and non-beneficiary group of water management

\begin{tabular}{llc}
\hline $\begin{array}{l}\text { Actual } \\
\text { Difference } \\
(\%)\end{array}$ & Item & $\begin{array}{l}\text { Contribution in } \\
\text { difference }\end{array}$ \\
\hline 56.41 & & 95.54 \\
& Neutral + Non-Neutral & 4.54 \\
\hline
\end{tabular}


practices brought about an immediate upward shift in income from rice production. The contribution of input use was found to be 4.45 percent. It was also observed that the beneficiaries were better allocators of inputs when compared to non-beneficiaries. Which clearly brings about the impact of water management practices on rice crop using inputs without risk and harvesting better yields when compared to nonbeneficiary farmers.

\section{References:}

Alshi M.R.,(1981).Impact of Technological change on Production, Employment and Factor shares in Cotton Crop in Akola District (Maharashtra) Ph.D

Purohit KVM and H.G Shankaramurthy,(1995)." Impact of Watershed Development Programme on the production of Oil seed Crops in Bijapur District, KarnatakaAn Economic Analysis". National Bank News Review, (1): 23-38.

Venkariya S.B and R.L. Shiyani, (1999). Important of an Irrigation project on Groundnut production in South Saurashtra Zone of Gujurat. Agril. Econ. Res. Rev, Vo112 (1): $9-13$.

Kumar B., S.K Singla and R.S Dhawan, (1989). Impact of Water management on crop pattern and Resource use in Kandi Tract (Punjab), A case study of malidam" Indian Journal of Agricultural Economics, 44(3): 275. 